\title{
原琵論文
}

\section{分布型を考慮したAl手法による 実時間流出予測モデルの構築}

関井勝善 1) ポール ジェームス スミス 2) 小尻利治 3$)$

\author{
1)株式会社損害保険ジャパン \\ （テ160-8338 東京都新宿区西新宿1-26-1）
}

2) Optimatics Pty Ltd

(7/62 Glen Osmond Road, Parkside, South Australia 5025, Australia)

3) 京都大学防災研究所水資源環境研究センター

（６11-0011 宇治市五ヶ庄）

近年，流域の各地で台風や集中豪雨による氾濫被害が多発しており，流域全体の流出状況を把握する必要が高ま ってきた．DEMなどの数值情報が整備され分布型流出モデルの適用が提案されている．しかし，実時間での洪水予 測と言う観点からは, より迅速で精度の良い方法を求められている。そこで本研究では, 流域の各地点の河川流量 状況を実時間で把握し，人工知能手法を利用して実時間での分布型洪水予測の開発を行うものである. 分布型流出 モデルのパラメータ同定にはパーティクルフィルタを適用し，実時間での流出モデルとして状態空間型ネットワー ク法を採用する。ネットワーク構造の最適化には最適ブレインダメージ法を導入し, 不必要な結合の削除と予測の 効率化を図る，なお，長良川流域での適用を行い，その有効性を確認する.

\section{キーワード：分布型洪水予測, 人工知能手法, パーティクルフィルタ, 状態空間型ネットワーク法,} 最適ブレインダメージ法

\section{I 。序文}

近年, 大規模な風水災害が地球規模で増加し, 世 界各地で多大な被害が出ている。日本でも最近，台 風や集中豪雨を原因とする大規模な水害が発生して 扔り, 人的, 経済的損失も甚大になっている. 現在, 任意地点に扔ける洪水予測情報を把握するため, 分 布型流出モデルの導入が試みられている。その結 果, 避難の際の詳細な情報の提供だけでなく, 排水 機場, 水門などの適切な操作, 堤防の補強といった 構造物の応急処置, といった洪水対策が効果的にな り，種々の損失を抑えることができると期待されて いる.

一方, 人口知能手法 (Artificial Intelligence technologies: AI）は, 水文デー夕の補完や計算処理の迅速性に より洪水予測にも利用されるようになり，イタリア やカナダでニューラルネットワーク (Artificial Neural Network:ANN）を用いた流出予測モデルが提案され ている (Campolo et al., 1999, Zealand et al., 1999). 野
原他（2005）も洪水, 渴水時の貯水池操作支援シス テムの構築において, 降雨量, 河川への流入量予測 にニューラルネットワークの適用を提案している.

以上の点より本研究では, $\mathrm{AI}$ 手法を用い分布型流 出過程を考慮した実時間洪水予測手法の開発を目指 すものであり， $\mathrm{AI}$ 手法と実時間補正手法の結合をは かる. 言い換えると, AI手法により, i) 分布型流出 モデルのパラメータ同定と, ii) 分布型としての実時 間洪水予測を行うものである (図一1参照)。具体的 には, レーダ雨量計などの降雨情報を利用して流出 予測を行うものであり, まず，分布型流出モデルを 導入しパーティクルフィルタによりパラメータ同定 を行う。パラメータが決まると分布型流出モデルで の計算流量を用いてAI手法による予測方法を構築す る。そして作成したAI手法で実時間での流量予測を 実施する。この研究では, パラメー夕同定はオフラ インで実時間予測はオンラインを念頭に展開されて おり，それぞれ別のデータセットとみなされている。 


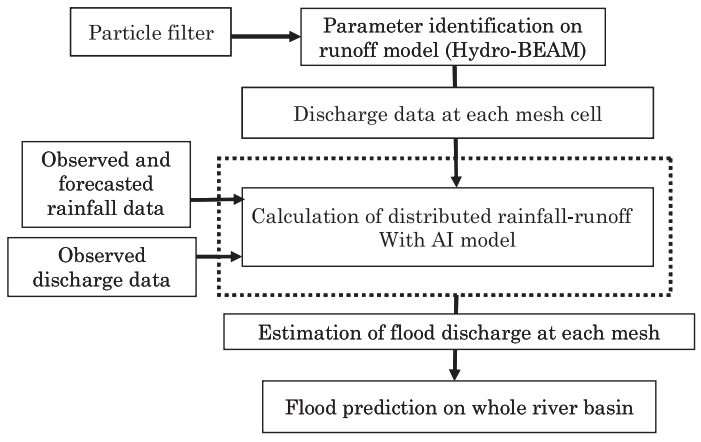

図-1 AIによる分布型流出予測モデルの作成手順

Fig.1 Research procedures for distributed runoff prediction with AI technologies.

故に，実時間では降雨予測は行わず，レーダ雨量か ら AI（ニューラルネットワーク）による流量予測が 行われることになる.

\section{II . 対象流域のモデル化}

\section{1. $A \mid$ 手法を用いた分布型での実時間流出予測モ デルの構築}

流域内の全ての地点の流出特性を明らかにするた め分布型流出モデルの導入を図るが, 具体的には, 流出モデルとして, 平常時, 降水時, 無降水時の流 域環境状況を連続的に把握できるグリッド型のモデ ルHydrological River Basin Environmental Assessment Model（Hydro-BEAM）（小尻他，1998）を導入する. この流量をAI手法によって再現することで, 分布型 での実時間予測の適用可能性を明らかのするもので ある. Hydro-BEAMでは単位メッシュを地画セルと 河道セルに分け，多層（4層）メッシュの表層には1 次元Kinematic Wave法を適用する。すなわち，

$$
\begin{aligned}
& \frac{\partial h}{\partial t}+\frac{\partial q}{\partial x}=r(t, x) \\
& q=\alpha \cdot h^{m}
\end{aligned}
$$

ここに, $A$ :流積 $\left[\mathrm{m}^{2}\right], q$ 流量 $\left[\mathrm{m}^{3} / \mathrm{hr}\right], t$ : 時間 $[\mathrm{hr}], x$ :位 置 $[\mathrm{m}], r$ :横流入量 $\left[\mathrm{m}^{3} /(\mathrm{m} \cdot \mathrm{hr})\right]$, である. A D 層は 地下水層としてダルシー則に基づく線形貯留式

$$
\begin{aligned}
& \frac{d S}{d t}=I-O \\
& O=k S
\end{aligned}
$$

を用いる.ここに, $S$ : 貯留量高 $[\mathrm{m}], I:$ 流入速度 $[\mathrm{m} / \mathrm{h}]$, $O:$ 流出速度 $[\mathrm{m} / \mathrm{h}], k:$ 浸透係数 $[1 / \mathrm{h}]$, である. 単位
メッシュからの流下方向を縦横斜方向の計8方向とし, メッシュごとの流下方向を合成して水系全体の落水線 モデル構造とする。河道網，地下水も単位メッシュと 同様に8方向とする. 河道は集水面積に相当する単位 メッシュ個数を閾值として, 閾值を超えた単位メッシュ から形成されると考えており, 落水線の一部か河道網 となる. 用いた単位メッシュの規模は $1 \mathrm{~km} \times 1 \mathrm{~km}$ の矩 形構造である.

\section{2. 対象流域}

研究対象の長良川（忠節上流域：1,607 $\mathrm{km}^{2}$ ) は, 大日岳に源を発し南東に流下しながら郡上八幡にお いて吉田川, 龟尾島川と合流し，その下流で板取川 と合流後に濃尾平野に出て南西に流れる。さらに, 津保川, 武儀川, 伊自良川を合わせて南流し, 揖 斐川と合流する流域面積 $1,985 \mathrm{~km}^{2}$, 幹川流路延長 $166 \mathrm{~km}$ の河川である。図一2はメッシュ化された流 域（1556メッシュ）で, 斜面メッシュ806, 河道メッ シュ750メッシュを表している。流出モデルの基本 パラメー夕は, 土地利用情報や従来の研究成果をも

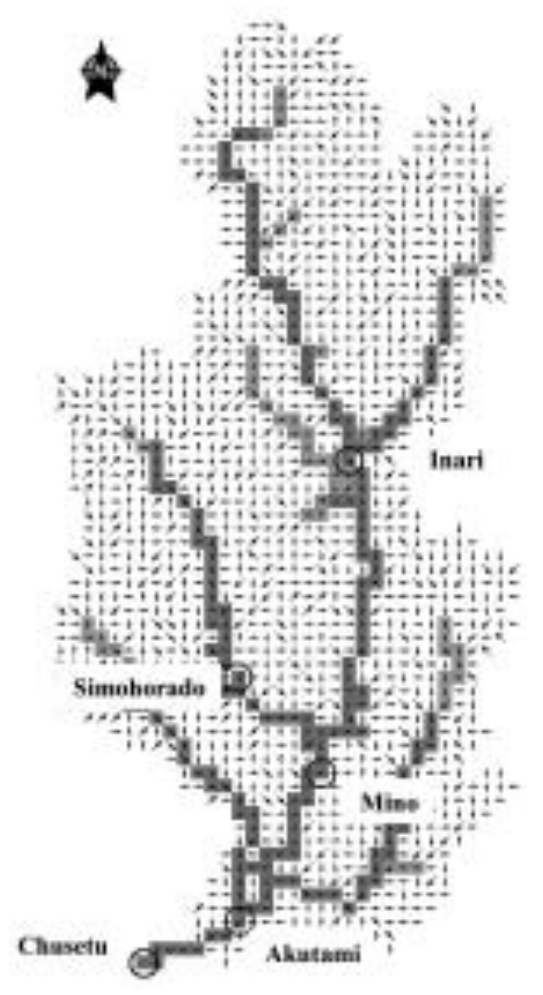

図－2 メッシュ化された長良川流域（忠節上流域）

Fig.2 Flow routing map of the Nagara River Basin. 
とに決定した，使用する洪水としては，2000年〜 2004年間の大きな洪水を用いる．洪水1（2000年9月 10日～12日；忠節での最大流量5041.0 ( $\mathrm{t} / \mathrm{s})$ ) と洪 水2（2002年7月8日～10日；同5334.0 (t/s) ) を学習 用デー夕，洪水3（2002年7月15日〜17日；同4254.0 $(\mathrm{t} / \mathrm{s})$ ) を検証用デー夕，洪水4（2004年6月20日〜22 日；同3791.0（t/s)）を実時間でのシミュレーショ ン用データとする。

\section{III. パーティクルフィルタによるパラメータ 同定}

\section{1. パーティクルフィルタの適用手順}

パーティクルフィル夕は状態遷移が非線形で表さ れる事象の状態推定に用いられるフィルタリング手 法である（Bolic, 2004）。概念的にはベイズ理論の 応用であり, 事後確率密度関数 $p\left(x_{k} \mid Z_{1, k-1}\right)$ は, 以下 のように定式化される.

$$
p\left(x_{k} \mid Z_{1, k}\right)=\frac{p\left(z_{k} \mid x_{k}\right) p\left(x_{k} \mid Z_{1, k-1}\right)}{p\left(Z_{k} \mid Z_{1, k-1}\right)}
$$

ここに, $x_{k}$ : 状態数, $k$ : 時間, $Z_{1, k}$ : 観測值系列, $Z_{k}$ : 観測值, である.しかし, $p\left(x_{k} \mid Z_{1, k}\right)$ を直接求めること は困難で, パーティクルフィルタでは, モンテカルロ手 法での乱数による積分計算を用いる.すなわち, 以下 のように近似される。

$$
p\left(x_{k} \mid Z_{1, k}\right) \approx \sum_{m=1}^{M} w_{k}^{(m)} \delta\left(x_{k}-x_{k}^{(m)}\right)
$$

ただし, $w_{k}^{(m)}$ : 事後確率密度関数の正規化された重要 度,である.式(6)において， $\delta$ はデル夕関数である. パーティクルフィルタでは, 多数の状態数 $x_{k}$ のサンプ ルを発生させ, 各サンプルに重要度 $w_{k}^{(m)}$ をちる。 $w_{k}^{(m)}$ は, $m$ 番目のサンプルによる状態遷移が観測值 系列を出力する可能性を表している.

$$
w_{k}^{(m)}=w_{k-1}^{(m)} p\left(Z_{k} \mid x_{k}^{(m)}\right)
$$

$p\left(x_{k} \mid Z_{1},{ }_{k}\right)$ は, 時間 $k$ において, 状態数 $x_{k}$ が観測值 系列を出力する可能性となる。流出モデルのパラ メー夕同定は解を持たない最適值問題であると考え られので，パーティクルフィル夕を予測手法として は用いず, 最適值問題の解決として適用する.

\section{2. パラメータ同定の能力検証}

状態変数として, 表面層から地下層への浸透能と
河川粗度を選択した。浸透能は流出流量の大きさに 影響を与えるパラメータであり，河川粗度は洪水の ピーク時間を合わせる際に大きな影響を与えるパラ メータである。パーティクルフィルタを用いたパラ メー夕同定の手順をまとめると，以下のようになる. i. 状態数の初期值に一様分布のノイズを与えて多数 の状態数（サンプル）をランダムに発生させる.

$$
\begin{array}{ll}
x^{m}=\left(r^{m}, s^{m}\right) \quad(m=1, \cdots, M) \\
r^{m}=r^{0}+u_{r}^{m} \quad\left(u_{r}^{m} \approx u\left(-0.5 r^{0}, 0.5 r^{0}\right)\right) \\
s^{m}=s^{0}+u_{s}^{m} \quad\left(u_{r}^{m} \approx u\left(-0.5 s^{0}, 0.5 s^{0}\right)\right)
\end{array}
$$

ただし, $r^{m}$ : 河川粗度 $\left[\mathrm{s} / \mathrm{m}^{1 / 3}\right], s^{m}$ : 地下層への浸透能 $[\mathrm{mm} / \mathrm{hour}], r^{0}$ : 河川粗度の初期值 $\left[\mathrm{s} / \mathrm{m}^{1 / 3}\right], s^{0}$ : 浸透能の 初期値 [mm/hour], $M$ :サンプル数, である.

ii. 各サンプルを使って流量計算を行い，観測点に おいて計算誤差を求め, 各サンプルに重要度変 数（重要度）を決定する。

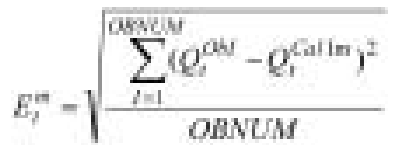

$$
w_{t}^{* m}=w_{t-1}^{m}\left(\frac{E_{t}^{m}}{\mu_{E}}\right)^{-2} \quad(m=1, \cdots, M)
$$

ただし, $t$ : 時間 [hour $], \mu_{E}: E_{t}^{m}$ の平均值 $[\mathrm{t} / \mathrm{s}]$, $O B N U M$ : 使用する流量観測所の総数, $Q_{t}^{O b I}$ : 観測点 $I$ における観測流量 $[\mathrm{t} / \mathrm{s}], Q_{t}^{\text {Cal Im }}$ : 観測点Iにおける計 算流量 $[\mathrm{t} / \mathrm{s}]$ ，である。

iii. 重要度（重み）を正規化する。

$$
w_{t}^{m}=\frac{w_{t}{ }^{* m}}{\sum_{j=1}^{M} w_{t}{ }^{*} j}
$$

iv. 再サンプリングを行い，新しいサンプルを使っ てステップ2を行う。

v. サンプルの重みつき平均值を出し, 最適な状態 数を決定する.

$$
x^{e}=\sum_{m=1}^{M} w_{t}^{m} x^{m}
$$

再サンプリング手法には一般的に使われる手法の1つ である残差再サンプリング法 (Residual Resampling:RR) を適用するが，その適用手順は次のようになる。

(1) サンプル $m$ の重要度と再サンプル数との積の整 
数部分をサンプル $m$ の複製因子数 $r^{m}$ とする.

(2) $r^{m}=\left[w^{m} N\right]$

ただし， $N$ : 再サンプル数，である。

(3) 各サンプルにおいて式（14）の操作を行い, 各 サンプルの複製因子の総和が再サンプル数に達 した時は，再サンプリングを終了する。

(4) サンプルの複製因子の総和が再サンプル数に達 しなかった時は， $N_{r}$ と各サンプルの新しい重要 度を以下のように設定する。

$$
\begin{aligned}
& N_{r}=N-\sum_{j=1}^{M} r^{j} \\
& w_{r}^{{ }^{*} m}=w^{m} N-r^{m} \\
& w_{r}^{m}=\frac{w_{r}^{{ }^{*} m}}{\sum_{j=1}^{M} w_{r}^{{ }^{*} j}}
\end{aligned}
$$

(5) 次に， $N_{r}$ を各サンプルに新しい重要度をもとに配 分を行い, $r^{m}$ を決める。すなわち，一様乱数Uを 発生させる $\left(U \approx u\left[0,1 / N_{r}\right]\right)$.

(6) サンプル $m$ の $C^{m}$ を以下のように設定する.

$$
C^{m}=\sum_{j=1}^{m} w_{k}^{j}
$$

(7) $C^{m}$ とUを比べる. $C^{m}$ がUより小さい場合は操作を終 え, $r_{r}^{m}=0$ とする. $C^{m}$ がUより大きい場合はUを複 製因子が足らないとみなし, 以下のようにUを更新し て, $C^{m}$ より值が大きくなるまでUの更新を繰り返す. Uの更新した回数を $r_{r}^{m}$ とする.

$U=U+\frac{1}{M}$

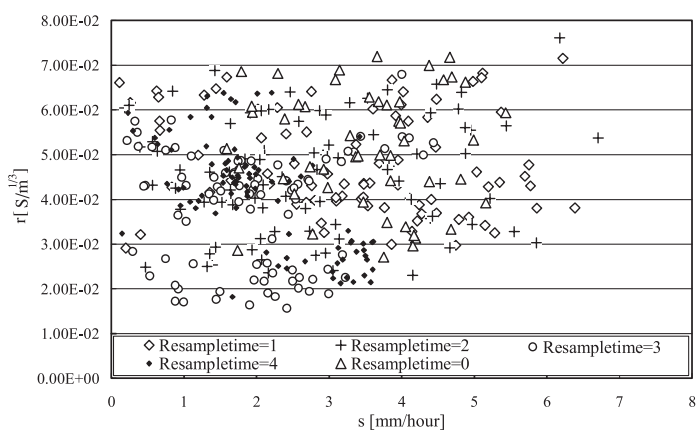

図－3 同定時におけるパラメータセットの分布

Fig.3 Distribution of parameter sets for identification processes.
(8) $r^{m}$ を更新して再サンプリングを終える.

$$
r^{\prime m}=r^{m}+r_{r}^{m}
$$

\section{3. パーティクルフィルタの適用性検証}

パーティクルフィルタを操作していく上で設定す ベきパラメータの例を表ー1に示す。サンプル数， 再サンプル数はともに30個である。使用する観測点 は下洞戸，美濃，忠節の3点，再サンプリング回数 は4回とする。同定の際に再サンプリングを行う夕 イムステップは，下洞戸に拈いてピーク流量に達す る時点から忠節で流量がピークに達する時点までの 中から4タイムステップを選択した. 3洪水において， パーティクルフィルタによるパラメータ同定を行 い，パラメータ分布の変化を表示した (図一3参照). さらに，洪水毎に再サンプリングを4回行った後の サンプルの分布を表示した（図一4参照).

図一3から，再サンプリングを行うことでサンプ ル点がまとまっていき, サンプルの分布が縮小さ れていっていることがわかる。再サンプリングを 4 回行うことで， $s$ が1.5〜2.1.に，rが0.04〜0.05に固 まっているサンプル群と, $s$ が3〜3.5.に， $r$ が.0.02〜 0.03 に固まっているサンプル群の2群が存在してい る。図一4を見ると，第 1 群は洪水 1 と洪水 2 のサンプ

表一1 パーティクルフィルタに用いたパラメータ值

Table 1 Parameters for particle filtering.

\begin{tabular}{c|c}
\hline Parameter & Value \\
\hline$M$ & 30 \\
$N$ & 30 \\
OBNUM & 3 \\
Resampling time & 4 \\
\hline
\end{tabular}

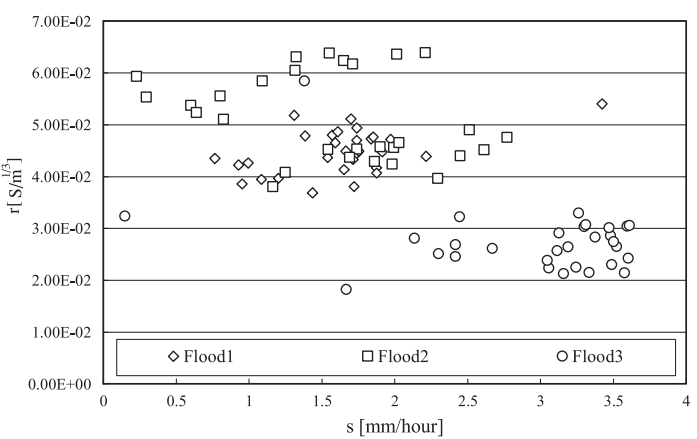

図－4 再サンプリング後のサンプルの分布

Fig.4 Distribution of samples after re-sampling processes. 
ル群で, 第2群が洪水3のサンプル群であることがわ かる．原因としては， $s$ と $r$ 外にもきちんと同定す ベきパラメータが存在することであろう.すなわち， 各洪水の初期状態を出来るだけ考慮することであ る。この結果から，実時間で分布型流出モデル使用 する際は，洪水となる時点より前に計算を始め，か つ, 洪水毎にパラメータを少し変えて計算すること が必要である。

\section{IN．SSNNによる分布型流出子测モデル}

\section{1. 状態空間型ニューラルネットワーク}

状態空間型ニューラルネットワーク (State-Space Neural Network : SSNN）は，時系列，空間把握を表 現できるニューラルネットワークの総称である。今 回, 分布型流出モデルに使用するSSNNとして, E1manの提案しているリカレントネットワーク (Elman,1990) を採用する.

まず，一般的なニューラルネットワークの一般式 を示す。

$$
\begin{aligned}
Z_{k, j} & =w_{k, j}^{0}+\sum u_{k-1, i} w_{k, j}^{k-1, i} \\
x_{k, j} & =\phi\left(Z_{k, j}\right)
\end{aligned}
$$

ここに, $Z_{k, j}: \mathrm{k}$ 層 $\mathrm{j}$ 番目のニューロンへの入力值, $w_{k, j}^{k-1, j}: \mathrm{k}$ 層j番目と $\mathrm{k}-1$ 層i番目のニューロンとの結合荷 重, $w_{k, j}^{0}: \mathrm{k}$ 層i番目の閾値, $u_{k, j}: \mathrm{k}-1$ 層墦目のニュー ロンの出力值, $x_{k, j}: \mathrm{k}$ 層 $\mathrm{j}$ 番目のニューロンの出力 值, ゆ:伝達関数, であり, $\left(Z_{k, j}\right)$ 伝達関数には次 のシグモイド関数を選択する.

$$
\phi(Z)=\frac{1}{1+e^{-Z}}
$$

Elman-RNNは中間層（隠れ層）のニューロンを記憶 し，次の時間ステップの際に入力值の一部として利 用する機能を持つネットワークである. 従って, 時 系列や空間的相関を把握できるモデルであるため, 流域の分布を把握し, 降雨の時系列から流域の各地 点の流出量を計算する分布型流出モデルに適してい ると言える。ここで, Elman -RNNの定義を式で表 すと以下のようになる。

$$
\begin{aligned}
& X(t)=\Phi(X(t-1), U(t), V) \\
& Y(t)=\Phi(X(t), W)
\end{aligned}
$$

$$
\Phi(Z)=\left(\phi\left(Z_{1}\right), \phi\left(Z_{2}\right), \cdots, \phi\left(Z_{N}\right)\right)^{T}
$$

ただし,$U(t)$ : 入力ベクトル,$X(t)$ : 状態べクトル,$Y$ $(t)$ : 出力ベクトル $, V, W:$ パラメータベクトル (荷重, 閾值), $N: Z$ の総数, である.

\section{2. 誤差逆伝播過程}

SSNNの教師付き学習方法としては，一般的な フィードフォワード型のニューラルネットワークに 用いられる誤差逆伝播法を適用する。誤差逆伝播法 とは, 教師付き学習に抒いて, ネットワークの出力 值と与えられた教師信号の誤差を減らすための荷重 や閾値を補正する手法の1つである（Elman,1990）。 以下では, 誤差関数, パラメー夕補正の一般式を示 す。具体的には，次のようになる。

$$
\begin{aligned}
& E=\frac{1}{2} \sum_{i=1}^{m}\left(y_{i}-O_{i}\right)^{2} \\
& \delta W_{k, j}^{k-1, j}=-\eta \frac{\partial E}{\partial W_{k, j}^{k-1, j}}(\eta>0)
\end{aligned}
$$

ここに, $E$ : 誤差関数, $y_{i}$ : 教師信号, $m$ : 学習データの パターンの総数, $O_{i}$ : 出力層の $\mathrm{i}$ 番目のニューロンの出 力值, $W_{k, j}^{k-1, i}: \mathrm{k}$ 層のi番目のニューロンと $\mathrm{k}-1$ 層のj番目 のニューロンをつなぐ結合荷重, $\delta W_{k, j}^{k-1, i}: W_{k, j}^{k-1, i}$ の補正 量, $\eta$ : 学習係数, である.

ネットワーク構造の最適化はネットワークの学習 と同時に行う。ニューロンとニューロンの結合にお いて，比較的弱い結合を介して入ってきた入力值は ニューロンの計算にあまり影響を与えないと考え られる。そこで, 強度の低い結合を削除すること でネットワークの最適化を行うことになる，結合削 除によりネットワーク構造が最適化されたニューラ ルネットワークはより一般化, 具体的には過学習の 回避, 必要な学習データの削減, 学習スピードの上 昇等が期待できる。これが，最適ブレインダメージ 法 (Optimal Brain Damage:OBD) であり,ヘッセ行 列の対角要素に基づいて結合荷重の貢献度を見積も り, 貢献度の低い結合荷重を削除できる (Le Cun et $a l ., 1990)$. 学習が収束した後のネットワークの結合 荷重を $w$ とすると, 誤差の変化率 $\delta E$ はテイラー展 開より以下の式で表される。

$$
\begin{aligned}
\delta E=\sum_{x} g_{x} \delta u_{x} & +\frac{1}{2} \sum_{x} h_{x x} \delta u_{x}^{2} \\
& +\frac{1}{2} \sum_{x \neq y} h_{x y} \delta u_{x} \delta u_{y}+\cdots
\end{aligned}
$$




$$
\begin{aligned}
& g_{x}=\frac{\partial E}{\partial u_{x}} \\
& h_{x y}=\frac{\partial^{2} E}{\partial u_{x} \partial u_{y}}
\end{aligned}
$$

ここでは, $w_{i j}($ ニューロンiとニューロンjをつなぐ結合荷 重)のみに焦点を当て, $\delta E$ の増加量を求めるため, 要 素は $u_{x}$ のみとなる $\left(u_{x}=w_{i j}\right)$. $\delta E$ において, 第 1 項の $g_{x}$ は, 誤差逆伝播法に扔ける結合荷重の変化量に相当す る、いま, 誤差逆伝播法による学習が収束した後を想 定しているので, $g_{x}$ は0と近似できる. また,$u$ は $u_{x}$ の となるため, 対角近似を用いて第 2 項の $h_{x y}$ も 0 と近似す る. 最後に, 2 次近似で第 3 項以降を 0 と近似すると

$$
\delta E \cong \frac{1}{2} \sum_{x} h_{x x} \delta u_{x}^{2}
$$

と表すことができる. 結局, $h_{x x}$ は, 以下の式で表される.

$$
h_{x x}=\frac{\partial^{2} E}{\partial w_{i j}^{2}}
$$

ここで，ある結合荷重 $w_{i j}$ を 0 とした時 $\left(w_{i j} \rightarrow 0\right), w_{i j}$ 以 外の結合荷重を適宜調節して達成される $E$ の増加量 $\delta E$ を考える. $\delta E$ の増加量が少ない結合荷重は, ネッ トワークへの貢献度の低い結合荷重であると考えられ， 削除できることになる。ある結合荷重を 0 としたとき のEの変化によって結合組み合わせを決定し, 効率 の良いネットワークを構築するものである。すなわ

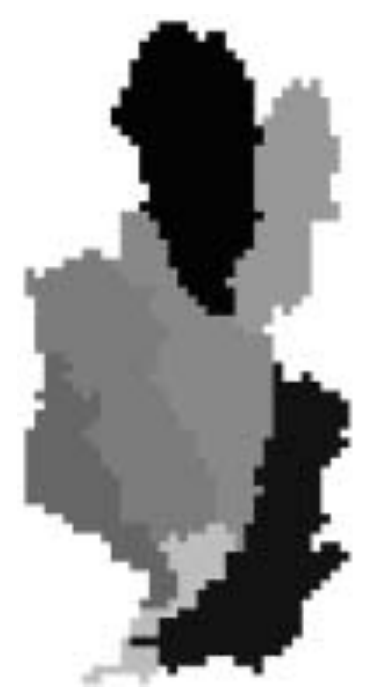

図 -5 適用に用いる流域分割

Fig.5 Divided sub-basins for application.
ち，誤差逆伝播法とOBDを用いたネットワーク構造 の決定手順はTresp et al. (1996) が提案している手法 を適用し，次のように要約される。

i. 中間層のニューロンの数 $\left(\right.$ Number $\left._{\text {pattern }}\right)$ を決める.

ii. 各結合荷重の初期值を設定する。初期值を乱数 器を用いる.

iii. 学習データを用いて誤差逆伝播を行い, 検証デー 夕の䛊差が増加したところで学習を止める.

iv. OBDを行い，結合荷重の一部を削除する。

v. 学習デー夕を用いて誤差逆伝播を再度行い, 検 証データの䛊差が増加したところで学習を止め る.

vi. 様々な各結合荷重の初期值のパターンを検証す るため，ii〜vを繰り返す。例えば，ニューロン 数の上限を 30 回と設定することもできる.

vii. 検証データの誤差が最も低い結合荷重の組み合 わせを選択する。

viii. iに戻って, 中間層のニューロン数を $1 つ$ 増やし て, ii以降を行う。

ix. 中間層のニューロン数が上限に達したら捜査を 終了する.

x. 検証データにおける精度が1番高いネットワーク 構造を選択する。

\section{3. 実流域での有効性検証}

適用時の入力值はレーダー雨量を利用するが，レー ダ観測雨量データをSSNNに入力する際，流域を河 川の形状に沿って7分割する (図一5参照)。分割流 域毎に1時間当たりの総雨量を出し, 各領域の雨量 を入力層の7個のインプット值とする (図一6参照).

ネットワークの学習の際に出力させる值として, 稲荷，下洞戸，美濃，芥見，忠節の 5 地点に抢ける

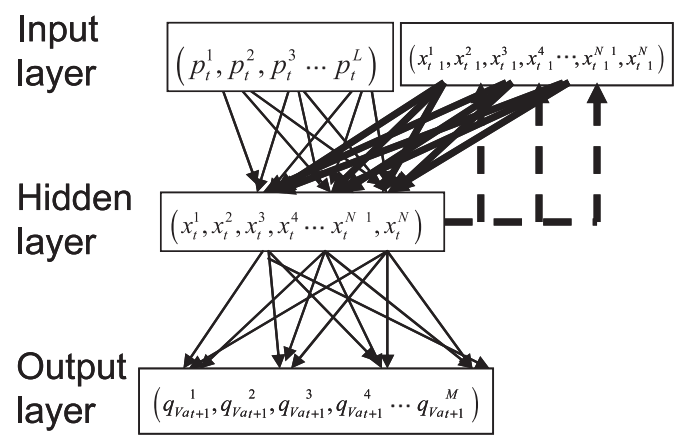

図－6 分布型流出予測のためのSSNN構造

Fig.6 SSNN structure for distributed runoff prediction. 
流量を選択する。つまり, 出力層のニューロン数は 5つである。 また, SSNNの出力の精度に使う指標と して，予めHydro-BEAMによって計算された推定流 量を用いる。つまり, 空間的に任意地点でのSSNN を作成する必要があり，誤差逆伝播法の適用に際し て, 任意地点へ展開を想定した解析が必要となる。 よって, SSNNでは, この5地点の出力值と HydroBEAMによる学習值とのSSNNによるモデル誤差を 低くするよう，学習することにする。ここで, 図中 の流量の変化量 $q_{V a t}^{k}$ を以下のように定義する。

$$
q_{\text {Vat }}^{k}=q_{t}^{k}-q_{t-1}^{k}
$$

ただし,$t$ はタイムステップ[hour],$L$ は入力層のニュー ロンの数, $N$ は中間層のニューロンの数, $P_{t}{ }^{k}$ は区分流 域にに扔ける雨量, $x_{t}$ は中間層の出力值, $M$ は流量を出 力したい流域地点の数, $P_{V a t}^{k}[\mathrm{t} / \mathrm{s}]$ は地点 $k$ における流 量の変化量を表す.この流出モデルでは, $t$ における状 態量 $x_{t}$ は, 入力值 $P_{t}^{k}$ と1ステップ前の $x_{t-1}^{1}, x_{t-1}^{2}, \cdots, x_{t-1}^{N-1}$, $x_{t-1}^{N}$ によって定まる. そして, 1ステップ先の地点 $\mathrm{k}$ スお ける変化量 $q_{\text {Vat }}^{k}$ は, $x_{t}^{1}, x_{t}^{2}, \cdots, x_{t}^{N-1}, x_{t}^{N}$ によって決定さ れる。 な拉，最初にSSNNを走らせる際 $(t=1)$ ，には $x_{0}{ }^{1}, x_{0}{ }^{2}, \cdots, x_{0}^{N-1}, x_{0}{ }^{N}$ を用意しなければならないが, 本 研究では,

$$
x_{0}^{i}=0(i=1,2, \cdots, N)
$$

とする

\section{4. ニューラルネットワーク構造の決定}

ネットワークの決定に際して, 中間層の二ューロ ンの数とOBDによって削除するネットワークの割 合を決める必要がある。図一7は，ネットワークの 学習前からネットワーク最適化に至るまでの経過を 示したものである。図に使用したSSNNの中間層の ニューロンの数は $18, \mathrm{OBD}+50 \%$ である、 $x$ 軸が学習

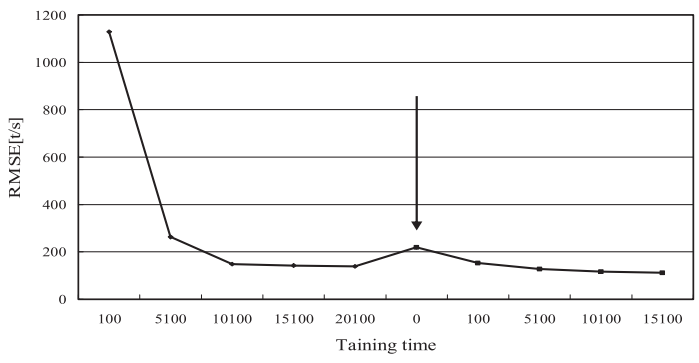

図一7 ニューラルネットワークの最適化過程

Fig.7 Optimizing process on neural network.
回数， $y$ 軸が検証デー夕を用いた，流域の5地点（稲荷， 下洞戸，美濃，芥見，忠節）に扔ける，SSNNの出力 值と予め求めたHydro-BEAMによる計算值との平均 二乗誤差（Root Mean Squared Error：RMSE）を示し ている。学習が22,100回でネットワークの荷重強度 が最適化されている。そして，OBDを行い（図の 矢印), 強度の弱いネットワークを削除している。 この時，OBDによるネットワーク削除によって， ネットワークの精度が悪くなり，RMSEが上昇して いることが見て取れる。その後，学習を再開して， 15,100回でOBD後のネットワークの荷重強度の最適 化が済んでいる。学習回数が異常に多いのは, 式 （29）に打ける，学習係数 $\eta$ を 0.0025 とかなり低く 設定したからである。図一8は中間層のニューロン の数とネットワークの精度との相関を示している. プロットした值は, 中間層に各ニューロン数を設定 した際の最適ネットワークに扔ける精度である。 OBDの削除率は60\%と設定する。一般的には, 最 適な中間層のニューロンの数は，入力層のニューロ ン数の1倍〜2倍程度であると言われている，同図か ら, 中間層のニューロンの数が9以上になると, 学 習データと検証データの精度が同等になり, 安定し ている. 入力層のニューロン数が7つであることを 考えると，一般論を反映している結果だと考えられ る。よって本研究では, 中間層のニューロン数を 9〜14から選択することにする，図一9は，OBDを行 う際のネットワークの削除率と, OBDによる, 検証 データにおける精度の変化の相関を示している， $x$ 軸はOBDのネットワークの削除率， $y$ 軸の值である 改善率は，中間層のニューロン数が9〜14に扔ける OBD後の検証データにおける精度をOBD前の精度 で割った值の平均值を示している。図では, OBD

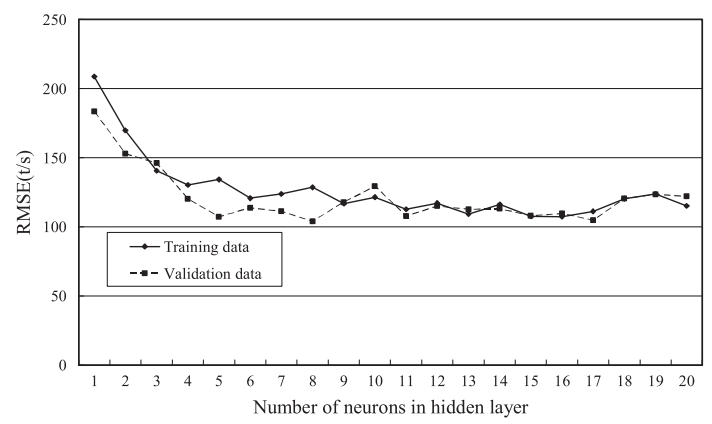

図 -8 中間層の数と予測精度との関係

Fig.8 Relationship between node number of hidden layer and predicted accuracy. 


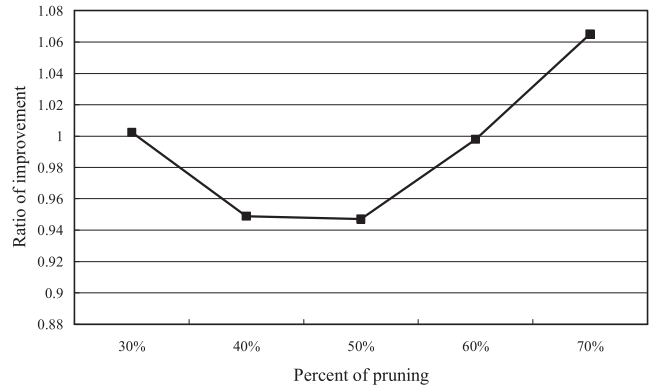

図－9 OBDでの削除率と精度の相関図

Fig.9 Relationship between reduction rate with OBD and predicted accuracy.

のネットワーク削除率が40％～50 \%の時，ネット ワークの精度の向上に成功している，削除率が50\% の時にネットワークの精度が最も向上している.よっ て，ネットワークの削除率を50\%に設定する。

\section{5. ニューラルネットワークの適用性評価}

ネットワーク決定手順に従って, 学習データ, 検証データの精度（RMSEの最小值）から中間層の ニューロン数が13個のSSNNを選択した。この SSNNを用いて, 洪水4に対してシミュレーションを 行った (図一10,11参照). 雨量は流域平均雨量を 表している。点線は観測流量, 実線はSSNNによる, 2004年6月21日13:00からの12タイムステップの出力 值を表している。全ての地点において, 雨量の増減 による, 流量の増減を表現できていると考えられる. また，全ての結果を図示していないが，下洞戸で は, SSNNによる流量のピーク值が観測流量の半分 になっており，ピーク時間が2時間ずれている．美 濃においては，ピーク時間にずれが生じている。美

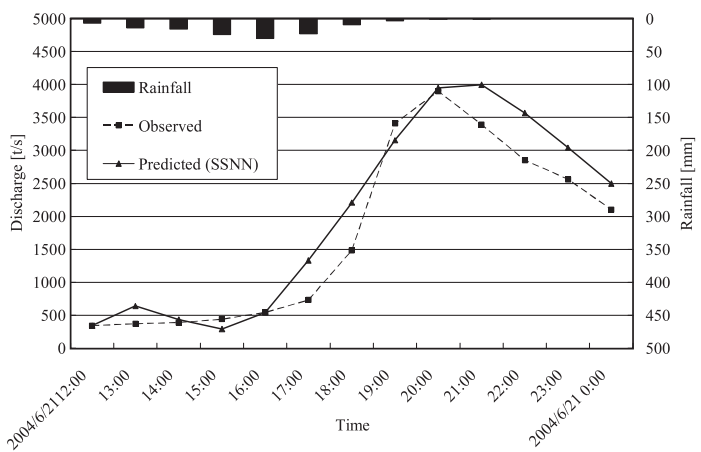

図-10 芥見でのシミュレーション結果（洪水4）

Fig.10 Simulated result on flood prediction at Akutami in the case of flood 4 .
濃では，SSNNによる流量のピーク值が観測流量の7 割程度になっている。また，ピーク時間は1時間ずれ ている。芥見, 忠節においては, ピーク時間, ピー ク流量，ともにほぼ一致しており，SSNNは極めて 精度の高い出力值を出していることがわかる.

\section{$V$ ．補正を加えた実時間洪水子测}

\section{1. 実時間流量補正手順}

実時間においても逐次補正が不可欠であり, SSNN の計算時の逐次補正にもパーティクルフィルタを使用 する. 従来型のフィルタリング手法（例えば, カルマン フィルタ）は観測点での逐次修正に力点が置かれてお り, 分布型流出モデルに適用するには, 流域内任意地 点での展開が困難となる.しかし, パーティクルフィル 夕は構造が簡単で, 流域全体への補正効果を期待でき るものである. Weerts et al. (2005) は, 流出モデル HBV-96にパーティクルフィルタと拡張カルマンフィルタ の1時間先流量補正を比較し, パーティクルフィルタの 優位性を示している。この成果を踏まえ, SSNNによる 分布型流出予測にパーティクルフィルタを適用する.

SSNNにフィルタリング手法を適用する際，状態 数を設定しなければならないが, フィル夕の状態数 になりうるものとしては,

1) 入力層の入力雨量 (入力ベクトル)

2) 中間層の出力值 (SSNNにおける状態ベクトル)

3） SSNNの結合荷重

がある。オフラインでの同定時には1）の雨量を フィルタリングの対象とする。すなわち,

$$
P_{\text {input }}=P_{\text {obs }}+\delta P \quad\left(\delta P \approx \operatorname{Normal}\left(0, \sigma_{\delta P}^{2}\right)\right)
$$

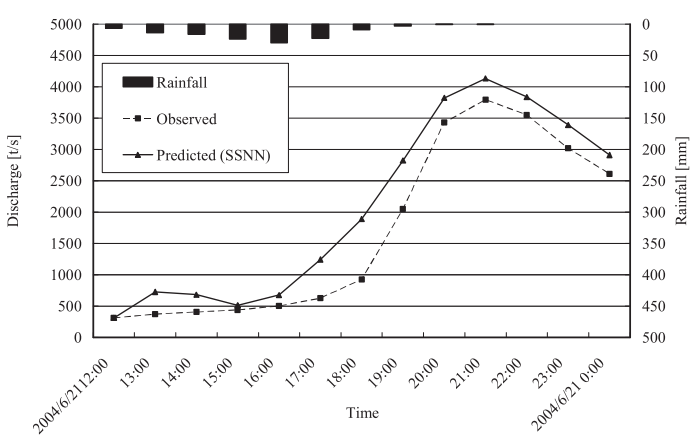

図-11 忠節でのシミュレーション結果（洪水4）

Fig.11 Simulated result on flood prediction at Chusetu in the case of flood 4. 


$$
\begin{gathered}
\sigma_{\delta P}=\alpha P_{o b s}+\beta \\
Q^{o b}=Q^{c a l}+\delta Q
\end{gathered}
$$

$\delta Q:$ 観測ノイズ $[\mathrm{t} / \mathrm{s}]\left(\delta Q \approx \operatorname{Normal}\left(0, \sigma^{2}{ }_{\delta Q}\right)\right)$

$$
\sigma_{\delta Q}=\gamma Q^{c a l}
$$

ここで，式 $(38) ，(40 ）$ の $\alpha, \beta, \gamma$ は定数とする. ただし，計算の簡便化のために $\beta$ を 0 とおく。状態サ ンプルを $\delta P$ と, 各サンプルの重要度変数（重要 度）は以下のように表される。

$$
\begin{aligned}
& w^{* m}=\frac{1}{\sqrt{2 \pi} \sigma_{\delta Q}^{2}} \exp \left[-\frac{E^{m 2}}{2 \sigma_{\delta Q}^{2}}\right]
\end{aligned}
$$

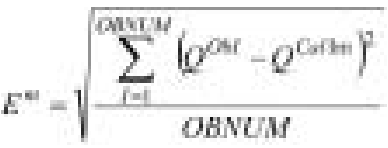

$$
\begin{aligned}
& w^{m}=\frac{w^{{ }^{*} m}}{\sum_{j=1}^{M} W^{* j}} \quad(m=1,2, \cdots, M)
\end{aligned}
$$

ここに, $M$ : サンプルの総数, OBNUM: 使用する流 量観測所の総数, $Q^{O b I}$ : 観測点Iにおける観測流量 $[\mathrm{t} / \mathrm{s}]$, $Q^{\mathrm{Cal} I \mathrm{~m}}$ :観測点Iにおける計算流量 $[\mathrm{t} / \mathrm{s}]$, である.

\section{2. 実時間補正の適用}

パーティクルフィルタによる実時間補正における $\alpha, \beta, \gamma$ を表一2のように設定する. 実時間補正の際 に観測地点は下洞戸, 美濃, 忠節とし, 観測点であ る芥見を検証地点として補正効果を調べる。シミュ レーション（洪水4に対しての適用）を行う際，6月 12日13:00〜16:00までの4夕イムステップの間，各ス テップでパーティクルフィルタを実施する。 そして, 6月12日16:00で雨量の補正值の更新を止め, 17:00以 降は同一の值で雨量補正を続けることにする。図一 12，13は芥見，忠節の結果を示している．忠節は観 測值を利用した補正であるが，芥見は検証地点であ

表-2 実時間補正で用いるパラメータ

Table 2 Parameters for real time correction.

\begin{tabular}{c|c}
\hline Parameter & Optimal Value \\
\hline$\alpha$ & 1.5 \\
$\beta$ & 0 \\
$\gamma$ & 0.1 \\
\hline
\end{tabular}

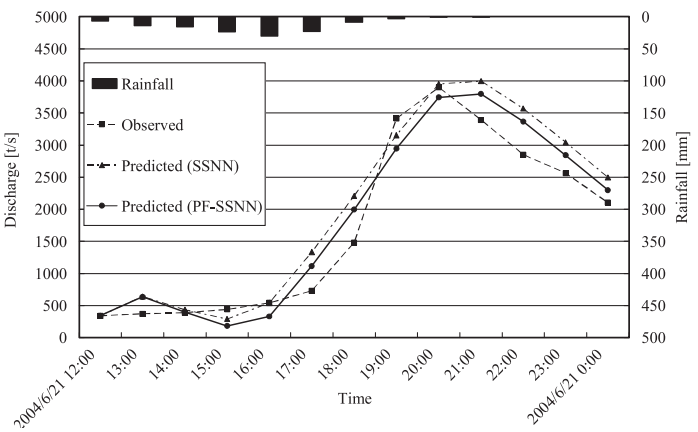

図-12 芥見での実時間補正結果

Fig.12 Result of real time correction at Akutami.
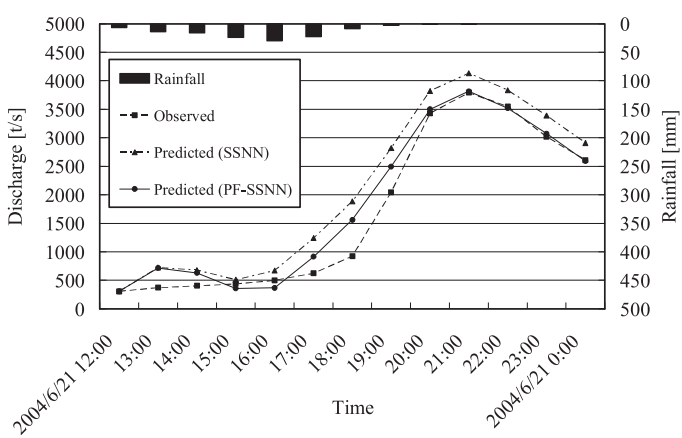

図-13 忠節地点での実時間補正結果

Fig.13 Result of real time correction at Chusetu.

り，空間的な推定による予測結果である。表一3は， 観測值と計算值の差の二乗平均和を求め, その平方 根值を観測地点全体で平均化し, 各予測方法の精度 を比較したものである，また，表中のNaive prediction とは, 現在の流量をそのまま必要な時間まで予測值 として伸ばしたものであり，補正は行っていない。 後の 2 種の予測は, 降水量を既知として, 流出過程で の流量予測とその補正と位置づけている。

全体的には流量ピーク時間のずれの補正は行われ てないが，流量補正は行われている，忠節では補正

表-3 平均二乗誤差での実時間補正の精度比較

Table 3 Comparison of RMSEs for real time correction.

\begin{tabular}{l|c|c|c}
\hline & $\begin{array}{c}\text { Naive } \\
\text { prediction }[\mathrm{t} / \mathrm{s}]\end{array}$ & SSNN [t/s] $]$ & $\begin{array}{c}\text { PF-SSNN } \\
{[\mathrm{t} / \mathrm{s}]}\end{array}$ \\
\hline 1hour-ahead prediction & 489 & 555 & 393 \\
2hour-ahead prediction & 1387 & 920 & 789 \\
3hour-ahead prediction & 2255 & 775 & 722 \\
4hour-ahead prediction & 2591 & 381 & 323 \\
5hour-ahead prediction & 2447 & 424 & 302 \\
6hour-ahead prediction & 2102 & 454 & 336 \\
\hline
\end{tabular}


による効果がかなり見られる，芥見では，ピーク流 量の精度が少し下がって扔り, 図で示されていない が，下洞戸では少し補正の効果が見られる。美濃で もRMSEで見ると少し補正の効果が見られるよう に，全体として精度はかなり向上している．時間的 な推移を見ると，1時間先では現在の流量をそのま ま使っても洪水予測に供することは出来るかもしれ ないが，2時間以降は補正を加えた予測の有効性が 顕著となる。避難などの実用性を考えると，補正の 重要性が理解できる.

次に, SSNNによって下流域の河川流量分布を把 握するため, SSNNの出力層のニューロン数を対象 流域の下流部分における, 河道メッシュ数である 65 に設定して, 下流域の各河川地点の流量を出力でき るようにした。なお，中間層のニューロン数を9〜 15 に設定し，ネットワークの削減率を50\%とした 結果, 中間層はOBDにより13個が得られた。これ らの数值は, 実時間制御全体において固定としてい る. 6月12日13:00〜16:00までの4タイムステップの 間にパーティクルフィルタを用いて流量の更新を行 い，17:00〜22:00までの間，更新を行わず実時間補 正を行った。図一14は，実時間補正されたSSNNが

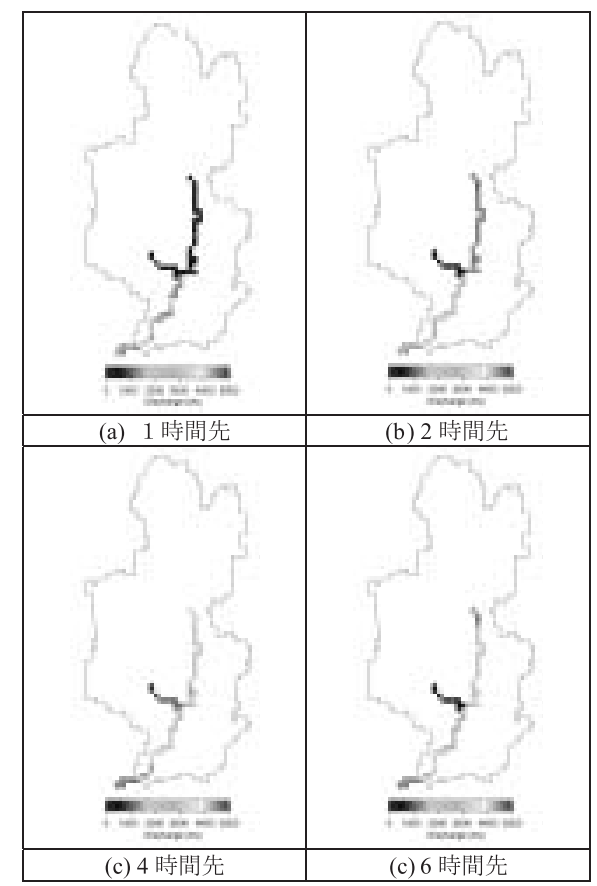

図－14 空間分布としてみた流出予測 (21/6/2004,16:00～)

Fig.14 Predicted results of spatial distribution, 16:00 21/6/2004.
出力した流量分布を空間的に可視化したもので, 洪 水流の強度分布, 言い換えると危険地域が容易に理 解できる。

\section{VI. 結語}

本研究では, 洪水予測に㧍けるAI手法の新たな適 用手法の提案を図ったもので, 実流域での適用を通 じて検証を行った。 また, 分布型流出モデルHydroBEAMのパラメータ同定にはパーティクルフィルタ を適用した。分布型流出モデルとして, AI手法の状 態空間型ニューラルネットワーク（SSNN）を選択 した. SSNNの学習手法には誤差逆伝播法を選択し た。得られた成果は以下のと抢りである。

1）パーティクルフィルタによる流出モデルパラメータ の同定法を提案した。その結果は適用可能性が高 く，実流域で活用できることがわかった。

2) SSNNの学習に最適ブレインダメージ法（OBD） を適用することで，ネットワークの検証データ に抢ける出力值の精度の向上が見られ, ネット ワーク構造の最適化を行うことができた。

3） SSNNによる流域5地点の流量を把握する分布型 流出モデルを作成した。このモデルにより，時 空間相関を考慮した流量分布状況を把握できた。

4）パーティクルフィルタによる入力データ補正に よって, 実時間使用におけるSSNNの計算值の精 度が向上した。

こうしたAI手法による実時間分布型洪水予測モデ ルは, 分布型流出モデルによる実時間洪水予測に比 べて, 計算時間が短く, 実時間補正が効いているの で, 実時間の流量情報を十分反映していると言える。 なお，提案している人工知能を活用した洪水予測や

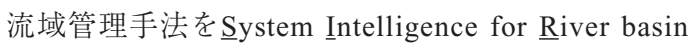
Operation Model（SIROM）と名付け, さらなる展開 を図りたい。

\section{参考文献}

Bolic, M. 2005. Architectures for efficient implementation of particle filters. Ph.D. thesis, State University of New York. Campolo, M., Andreussi, P. and Soldati, A. 1999, River flood forecasting with a neural network model, Water Resour. Res. 35 (4): 1191-1197.

Elman, J. 1990. Finding structure in time. Cognitive Science 14: 179-211.

小尻利治・東海明宏・木内陽一 (1998) : シミュレーションモデルで の流域環境評価手順の開発, 京都大学防災研究所年報, 第41号 B-2, pp.119-134. 
Le Cun, Y., Denker, J. S. and Solla, S. A., 1990. Optimal brain damage, Advances in Neural Information Processing Systems 2, Morgan Kaufman.

Lees, M., Young, P., Ferguson, S., Beven, K. and Burns, J. 1994. An adaptive flood warning scheme for the River Nith at Dumfries, 2nd international conference on river flood hydraulics, John Wiley \& Sons Ltd.

野原大督・小尻利治 (2006) : 地球規模気象情報を考慮した学習 型貯水池操作支援システム, 水文・水資源学会誌 第19号第1 号, pp.25-43.
Tresp, V., Neuneier, R. and Zimmermann, H.G. 1997. Early brain damage, Advances in Neural Information Processing Systems 9. MIT Press.

Weerts, A.H. and El Serafy, Y.H. 2004. Particle filtering and ensemble kalman filtering for runoff nowcasting using conceptual rainfall runoff models, Report number: Q3450, WLDelft Hydraulics, The Netherlands.

Zealand, C.M., Burn, D.H. and Simonovic, S.P. 1999. Short term streamflow forecasting using artificial neural networks. Journal of Hydrology 214: 32.

（受付：2006年8月10日，受理：2007年4月6日）

\title{
Modeling of Real-time Prediction with AI Technologies for Distributed Runoff Model
}

\author{
Katsuyoshi SEKII 1) Paul James SMITH ${ }^{2)}$ Toshiharu KOJIRI ${ }^{3)}$ \\ 1) Sompo Japan Insurance Inc. \\ (1-26-1 Nishi-shinjuku, Shinjjuku-ku, Tokyo, 160-8338, Japan) \\ 2) Optimatics Pty Ltd \\ (7/62 Glen Osmond Road, Parkside, South Australia 5025, Australia) \\ 3) Water Resources Research Center, DPRI, Kyoto University \\ (Gokasho, Uji, Kyoto 611-0011, Japan)
}

As the serious floods due to typhoon or concentrated heavy rainfall have been happened at many areas in the world, the total control system for the whole river basin is getting significant. The distributed runoff model can be provided through newly arranged mesh data and GIS technologies. From the viewpoint of real-time flood prediction to prepare the necessary countermeasures or actions, the system should keep the quick response and high accuracy against abnormal rainfall events with new methodologies. .In this research artificial intelligence is used to develop a distributed flood forecast system capable of real-time simulation of river flood levels at all locations within a watershed. Parameter calibration of a distributed rainfall-runoff model (Hydro-BEAM) is carried out using a particle filter, and real-time modeling of river discharge is enabled through the use of a State-Space Neural Network. Optimal training of the neural network is carried out using Optimal Brain Damage, which systematically reduces weak links in the network to allow for improved forecast efficiency and accuracy. An application is made for the Nagara River watershed to demonstrate the effectiveness of the system.

Key words : distributed rainfall-runoff model, artificial intelligence, particle filter, state-space neural network, optimal brain damage 